\title{
TORTOR HUSIP-HUSIP DALAM UPACARA KEMATIAN SAURMATUA PADA MASYARAKAT BATAK TOBA KAJIAN KOMUNIKASI NON VERBAL
}

\author{
YULI M SIDABUTAR \\ Prodi Pendidikan Tari
}

\begin{abstract}
This study aims to find out how non-verbal communication of Tortor Husip-husip in Batak Toba society. The population in this study are some of the traditional leaders Batak Toba society in Simanindo district, some of the artists who know about Tortor Husiphusip and the actors (citizens) who are involved as performer Tortor-husip Husip. The sample is also customary prominent figure, artists, and actors involved in Tortor Husiphusip.

The method is used descriptive qualitative method. To complete the data in this study, the research conducted field observations, video, interviews and also documentation.

The results of the data collected can be seen in non-verbal communication of Tortor Husip-husip in Batak Toba society, which is not only as a dance performed in ceremonies of death Batak Toba, but also can serve as a medium of communication and symbolic systems. The uniqueness and characteristic of this tortor are gotten in Husip-husip which has meaning how expressing of whispering, hopeful and prayers to those who have Saurmatua. As a medium of non-verbal communication can be seen from the gesture. The dancers are not only get dance as usual, but there are non-verbal messages will be conveyed through by gesture in Tortor Husip-Husip. The form of non-verbal communication in Tortor Husip-husip is symbolized by keep nodding head with body position leaning forward and whispering with a corpse. Gondang Bolon as the traditional music is used in this ceremonial celebrating. It contains sarune, taganing, gordang, ogung and hesek. The Non-verbal messages will be submitted to each community must be respecting to parents. And the Tortor Husip-husip is one of final tribute and delivering of the prayer, hope, gratitude and apology to the parents who have saurmatua.
\end{abstract}

Key word : TortorHusip-husip,Saurmatua, Batak Toba Society 


\section{Pendahuluan}

Kesenian sebagai salah satu unsur kebudayaan merupakan tiang yang menopang keberadaan masyarakat dalam berbagai upacara yang terdapat ditengah-tengah masyarakat, seperti upacara keagamaan (religi), upacara adat perkawinan, upacara adat kematian, upacara pemberian nama, dan berbagai macam aktivitas masyarakat lainnya. Kesenian juga menjadi sarana komunikasi baik dengan warga masyarakat maupun alam semesta dan sering hadir dalam berbagai aktivitas masyarakat.

Kesenian bagi masyarakat Batak Toba digunakan sebagai bagian dari segala kegiatan, baik sebagai media penyampai atau media komunikasi, ataupun disajikan sebagai hiburan dalam kegiatan. Bentuk seni yang disajikan antara lain adalah seni tari dan seni musik yang dalam bahasa Batak disebut Tortor (tari) dan Gondang(musik).Tortor pada masyarakat Batak Toba dilakukan dalam setiap kegiatankegiatan yang berbentuk upacara religi dan upacara adat. Masyarakat
Batak Toba percaya dengan menyertakan kesenian, maka tujuan dan keinginan akan tercapai. Kematian dan adat tradisinya dalam budaya Batak Toba memiliki perlakuan atau upacara serta adat yang berbeda-beda. Setiap orang yang meninggal dengan umur dan status, maka prosesi dari orang yang meninggal tersebut akan saling berbeda satu sama lain.

Meninggal setelah mempunyai keturunan dan keturunannya sudah menikah (Saurmatua) adalah kematian yang paling diidamkan oleh setiap orang pada suku Batak Toba. Hal ini didasarkan atas anggapan bahwa arwah jenis kematian Saurmatua telah mempunyai pengaruh terhadap keturunan yang paling hidup. Dengan mengingat pentingnya arwah itu, penghormatan perlu diberikan kepadanya berupa dilaksanakan dengan beberapa upacara, seperti upacara membunyikan musik tradisional (gondang).

Salah satu kegiatan peninggalan sejarah dalam upacara kematian pada masyarakat Batak 
Toba adalah TortorHusip- yang dikemukakan oleh Lary A husip.TortorHusip-husip ini dilakukan pada upacara kematian mate Saurmatua, TortorHusiphusipini menggambarkan tentang sukacita akan kematian ditingkatan Saurmatua karena seseorang dapat hidup hingga mempunyai cucu, dan sudah menikahkan anak-anaknya, dimana mengartikan bahwa semua berbahagia dan memberi penghormatan serta harapan akan Sahala orang yang mate Saurmatua akan memberi berkat dan jauh dari bahaya, dansemua keturunannya akanmenyatakan sesuatu dengan berbisik kepada jenazah yang mate Saurmatuatersebut.Hal ini menjadi istimewa karena terdapat unsur komunikasi non verbal yang melatarbelakangi Tortor Husip-husippada upacara adat Saurmatua. Untuk itu perlu dikaji dan diteliti bagaimana bentuk Tortor Husip-husip yang didalamnya terdapat keunikan pada Tortor Husip-husipnya.

\section{Landasan Teori}

Adapun untuk memahami komunikasi non verbal tersebut menimbulkan beberapa paradigma yang muncul salah satunya paradigma

Samovar dan Richard E Potter dalam buku Deddy Mulyana dimana komunikasi meliputi tujuh unsur yaitu ekspresi wajah untuk menyampaikan keadaan emosi dari seseorang kepada orang yang mengamatinya, waktu yang tepat dalam tujuan penyampaian pesan, ruang dimana tempat atau posisi dimana proses pesan non verbal itu terjadi, gerakan yang dapat menimbulkan kesan terhadap orang lain yang melihatnya, busana yang dikenakan, bau-bauan yang dipergunakan yang tercium wangi oleh publik, dan sentuhan yang dapat memiliki arti multi makna.

Interaksi simbolik adalah segala hal yang berhubungan dengan pembentukan makna dari suatu benda atau lambang atau simbol, baik benda mati, maupun benda hidup, melalui proses komunikasi baik sebagai pesan verbal maupun perilaku non verbal dan tujuan akhir adalah memaknai lambang atau simbol (objek) tersebut berdasarkan kesepakatan bersama yang berlaku di wilayah atau kelompok komunitas masyarakat tertentu.Berdasarkan penjelasan tersebut penulis menggunakan teori 
ini sebagai pendukung dari teori komunikasi non verbal dalam melihat interaksi yang terjadi pada saat peristiwa manortor dilakukan. Hal ini dikarenakan peristiwa manortormemiliki simbol-simbol yang menguatkan dari pesan yang mau disampaikan dari keluarga kepada yang meninggal

\section{Metodologi Penelitian}

Pelaksanaan penelitian ini dilakukan dengan menggunakan metode deskriptif dengan pendekatan kualitatif.Hal ini dimaksudkan untuk menggali data yang masih ada untuk memperoleh informasi yang diperlukan dalam penelitian.Metode ini dipilihkarena dapat memberikan keterangan yang akurat dan jelas sesuai yang dibutuhkan.

\section{a. Lokasi dan Waktu Penelitian}

1) Lokasi penelitian

Lokasi penelitian ini dilaksanakan di Kecamatan Simanindo Kabupaten Samosir, Sumatera Utara. Pemilihan tempat ini dikarenakan ditempat tersebut terdapat narasumber dan senimanseniman serta Tortor Husiphusipdalam upacara adat Saurmatua pada masyarakat Batak Toba masih dijalankan dan dilestarikan oleh masyarakat setempat.

2) Waktu Penelitian

Waktu pelaksanaan penelitian untuk mendapatkan data dan keterangan yang diperlukan berkaitan dengan materi dalam penelitian Tortor Husip-husipdalam upacara adat Saurmatua pada masyarakat Batak Toba adalah tiga bulan. Penelitian ini akan dilaksanakan dari awal Juni 2016 sampai Agustus 2016. Akan tetapi, sebelum penelitian dilakukan, penulis sudah melakukan beberapa kali pertemuan dan berdialog dengan narasumber mengenai topik permasalahan dan memastikan objek yang akan diteliti.

\section{b. Populasi dan Sampel}

\section{1) Populasi}

Populasi adalah wilayah generalisasi yang terdiria atas obyek/subyekyangmempunyai

kualitas dan karakteristik tertentu yang ditetapkan oleh peneliti untuk dipelajari dan kemudian ditarik kesimpulannya. Populasi dalam penelitian ini bersifat terbatas. Khususnya sebagai subyek dalam 
upacara kematian SaurMatua ini. menggunakan sampel yang terdapat

Berkaitan dengan penelitian ini, maka yang menjadi populasi dalam penelitian ini adalah beberapa tokoh adat masyarakat Batak Toba yang ada di Kecamatan Simanindo dan Kabupaten Samosir, seniman-seniman yang mengetahui tentang Tortor Husip-husipdalam upacara adat Saurmatua pada masyarakat Batak Toba serta pelaku (masyarakat) yang terlibat sebagai pelaku Tortor Husiphusipdalam upacara adat Saurmatua pada masyarakat Batak Toba tersebut.

2) Sampel

Sampel adalah bagian dari jumlah dan karateristik yang dimiliki populasi tersebut. Setelah populasi ditemukan dengan jelas dan perkiraan jumlah elemen/anggotanya diketahui, maka selanjutnya penulisan harus menganalisis apakah mungkin untuk meneliti seluruh elemen populasi atau perlu menganalisis sebagian dari populasi saja yang disebut dengan sampel. Sugiono (2009 : 118) menyatakan bahwa, "Sampel adalah bagian dari jumlah dan karakteristik yang dimiliki oleh populasi”. Apabila populasi besar maka peneliti dapat pada populasi tersebut. Untuk itu sampel yang diambil dari populasi harus betul-betul representative (mewakili).

Berdasarkan pernyataan diatas, adapun yang menjadi sampel pada penelitian ini adalah semua yang ada pada populasi yaituTiga orang tokoh adat pada masyarakat Batak Toba yang ada di Kecamatan Simanindo.Seniman dan pelaku (masyarakat) yang pernah terlibat dalam Tortor Husip-husipdalam upacara adat Saurmatua pada masyarakat Batak Toba di Kecamatan Simanindo

\section{c. Teknik Pengumpulan Data}

Teknik pengumpulan data yang dilakukan adalah sebagai berikut:

1. Studi kepustakaan

2. Observasi

3. Wawancara

4. Dokumentasi

\section{d. Teknik Analisis Data}

Sesuai dengan bentuk data yang terkumpul melalui wawancara, observasi, dokumentasi dan studi 
kepustakaan, data-data ini kemudian diolah dan dianalisis dengan teliti. Hasil olahan dan analisis tersebut dideskripsikan dalam bentuk tulisan ilmiah, kemudian diklasifikasi sesuai materi data tersebut dan akan diupayakan untuk memperdalam atau meginterpretasi data secara spesifik dalam rangka menjawab semua pertanyaan penelitian. Teknik data yang digunakan adalah analisis deskriptif kualitatif yaitu penelitian yang memberi gambaran, uraian, keterangan, dan mencari fakta. Analisis deskriptif kualitatif merupakan metode penelitian yang dilakukan sesuai fakta sosial untuk membahas mengenai Tortor Husiphusipdalam upacara adat Saurmatua pada masyarakat Batak Toba di Kecamatan Simanindo.

\section{ISI}

a. Gambaran Umum

\section{LokasiPenelitian}

KecamatanSimanindo

merupakan salah satu kecamatan yang terdapat di Provinsi Sumatera Utara Kecamatan Simanindo berada diantara : $2032^{\prime}$ - 20 45' Lintang Utara dan $98044^{\prime}$ - 980 50' Bujur
Timur.Kecamatan Simanindo merupakan satu kecamatan dengan luas wilayah kecamatan $198.20 \mathrm{Km}^{2}$ dan jumlah penduduk 20.190 jiwa dengan jumlah rumah tangga (RT) 5.042 RT. Dan di Kecamatan Simanindo penelitian ini dilaksanakan.

\section{b. Mata Pencaharian dan Sumber Daya Alam}

Pada umumnya masyarakat Kecamaan Simanindo mata pencahariannya adalah bertani dan nelayan, pada sebagian masyarakat berprofesi sebagai dokter dan guru, selebihnya ibu rumah tangga namun tingkat kebutuhan hidup semakin tinggi maka kebanyakan dari masyarakat beralih profesi membuka usaha dagang, pertukangan, bengkel, klasifikasi industri dan tukang jahit. Berhubung wilayah Kecamatan ini mendukung sebagai daerah pariwisata sehingga sangat memungkinkan pekerjaan ini memiliki banyak keuntungan. Selain itu masih terdapat sumber daya alam seperti sektor perkebunan, peternakan, dan perikanan serta peninggalan sejarah yang bermanfaat serta menjadi 
sumber mata pencaharian bagi diberikan oleh orang tuanya, masyarakat. Hal ini mendukung meninggal pada saat masih kanaktingkat pemasukan keuangan bagi kanak (mate dakdanak) tradisi atau setiap rumah tangga di Kecamatan Simanindo, selain tingkat kebutuhan hidup yang tinggi para masyarakat juga harus lebih bekerja keras demi mendapakan uang untuk memenuhi pelaksanaan adat, salah satunya pelaksanaan adat saurmatua yang membutuhkan biaya yang jumlahnya tidak sedikit.

\section{c. Upacara Kematian Pada}

\section{Suku Adat Batak Toba}

Dalam tradisi Batak orang yang meninggal akan mengalami perlakuan khusus, terangkum dalam sebuah upacara adat kematian. Upacara adat kematian tersebut diklasifikasi berdasarkan jenis kematiannya.

Adapun jenis kematian tersebut yaitu: meninggal pada saat di dalam kandungan (mate di bortian) tradisi atau prosesi adat kematian belum berlaku karena langsung dikubur tanpa peti mati, meninggal saat masih bayi (mate poso-poso) tradisi atau prosesi adat kematian yaitu jenazah ditutupi sebuah kain tenunan khas Batak (ulos) yang

prosesi adat kematian yaitu jenazah ditutupi ulos yang dilakukan oleh paman/saudara laki-laki dari ibu (tulang), meninggal pada saat remaja atau menjelang dewasa (mate bulung) tradisi atau prosesi adat kematian sama dengan mate dakdanak yaitu jenazah ditutupi ulos dari tulang, meninggal pada saat berusia dewasa namun belum menikah (mate ponggol) tradisi atau prosesi adat kematian sama dengan mate dakdanak dan mate bulung jenazah ditutupi ulos oleh tulang, meninggal pada saat sudah menikah namun belum memiliki keturunan (mate diparalang-alangan/mate punu), meninggal pada saat sudah menikah dan sudah mempunyai keturunan tetapi masih anak-anak (mate mangkar), meninggal pada kondisi sudah mempunyai beberapa anak yang sudah menikah namun belum memiliki cucu (mate hatungganeon), meninggal pada kondisi mempunyai cucu, namun ada anaknya yang belum menikah (mate sarimatua), meninggal pada saat anaknya sudah menikah 
semua dan sudah mempunyai cucu (mate saurmatua), meninggal pada saat anaknya sudah menikah semua dan sudah memiliki cucu yang sudah mempunyai keturunan (mate saurmatua bulung) ${ }^{1}$.

Dari beberapa jenis kematian diatas mate saurmatua merupakan upacara adat tertinggi dan menyertakan adat na gok, dan wajib dilakukan kegiatan margondang.

\section{d. Sistem}

Kekerabatan

\section{Masyarakat Batak Toba}

Sistem

kekerabatan

masyarakat Batak Toba merupakan falsafah hidup yang mengikat suatu hubungan tertentu dari seluruh pihak yang masuk dalam lingkaran kerabat masyarakat Batak Toba dan masingmasing mempunyai sebutan dalam status kekerabatan yang disebut "Dalihan Natolu”yang artinya sebuah tungku masak yang diletakkan diatas tiga batu sebagai penyangga. Dapat diartikan bahwa ketiga batu harus sama besar, dan diletakkan pada jarak yang sama antar batu dan dengan tinggi seimbang antara satu dan

\footnotetext{
${ }^{1}$ Lebih jelas tentang upacara saurmatua dapat dilihat dari tulisan Richard Sinaga, 1999:3742; Delfi Elias Simatupang)
}

lainnya supaya tungku yang diletakkan dapat berdiri kokoh.

Berikut makna Dalihan Natolu pada masyarakat Batak Toba terdiri dari Hula-hula. Hula-hulapada masyarakat Batak Toba adalah pihak pemberi istri atau saudara laki-laki ibu,dan disebut Tulang oleh anak. Dalam adat Batak Toba yang melakukan peminangan adalah pihak laki-laki maka pihak perempuan pantas dihormati karena memberi putrinya sebagai istri yang memberi keturunan kepada satu-satu marga, penghormatan tersebut tidak hanya diberikan kepada tingkat ibu akan tetapi sampai kepada tingkat ompung dan seterusnya. Hula-hula dalam adat Batak akan lebih kelihatan dalam upacara adat saurmatua peranan Hula-hula sangat dihormati dan dibutuhkan. Dongan tubu pada masyarakat Batak Toba adalah saudara semarga yakni orang-orang satu garis keturunan dengan bapak satu leluhur, gambarannya adalah abang adik. Atau dapat dikatakan sekelompok masyarakat dalam satu rumpun marga, dalam kehidupan sehari-hari hubungan antara abang- 
adik sangat erat. Namun suatu saat hubungan itu akan renggang, bahkan dapat menimbulkan pertumpahan darah karena demikian, maka orang Batak diperintahkan untuk selalu manat mardongan tubu yang artinya saling menghormati dan berhati-hati kepada saudara semarga agar tidak menyakiti hatinya dan Boru pada masyarakat Batak Toba adalah pihak saudara perempuan kita, dan pihak marga suaminya atau keluarga perempuan dari marga kita. Dalam kehidupan sehari-hari sering kita mendengar "elek marboru" yang artinya agar saling mengasihi supaya mendapat berkat.

\section{e. Sistem Religi}

Dalam kehidupan masyarakat Batak Toba mengenal tiga konsep menyangkut jiwa dan roh diantaranya, Sahala adalah jiwa atau roh kekuatan yang dimiliki seseorang yang telah meninggal, tidak semua orang memiliki Sahala. Sahala hanya dimiliki oleh orang yang baik semasa hidupnya dan berharap akan memberikan sesuatu hal yang baik yang minta oleh setiap keturunan kepada ompungnya dan menghormati
Sahala tanpa harus menyajikan sesajen atau melaksanakan pemujaan, cukup hanya dengan berdoa dan mengutarakan harapan, doa dan keinginan kepada Sahala ni ompung. Dalam upacara saurmatuapada masyarakat Batak Tobamenghormati sahala ni ompung adalah hal yang terpenting.

Sumanggot merupakan roh leluhur yang sudah meninggal menduduki tempat yang khusus. Terutama mereka diwaktu hidupnya mempunyai kekuasaan, kaya raya dan mempunyai keturunan yang banyak. Roh mereka ini sumanggot ni ompu (roh leluhur yang dipuja), ingin disembah dan dihormati dengan sesajen agar terus bergiat dalam memajukan kesejahteraan keturunan leluhur itu. Dengan demikian panen akan melimpah ruah, kekayaan bertambah, ternak berkembang biak, akan lahir banyak anak dan akan terhindar dari bencana. Tetapi jika roh itu dilalaikan, anak-anak akan mati, panen gagal, ternak jatuh sakit dan berbagai malapetaka lainnya datang menimpa. Melalui penglihatan gaib, Datu akan menanyakan apakah ada ancaman bahaya yang datang dari roh 
leluhur yang murka, sumanngot na tarrimas. Jika memang demikian halnya, datu akan menentukan berbagai macam pengurbanan yang harus dilakukan. Kadang-kadang, roh mengungkapkan keinginan dan kehendaknya melalui perantara, Sibaso yang kerasukan oleh roh pada suatu peristiwa khusus. Dilingkungan leluhur yang besar dan kecil, orangorang secara teratur menyajikan persembahan kepada leluhur jika sedang ada perjamuan dan gondang dipukul.

Tondi adalah jiwa atau roh seseorang yang merupakan kekuatan, oleh karena itu tondi memberi nyawa kepada manusia. Tondi didapat sejak seseorang di dalam kandungan. Bila tondi meninggalkan badan seseorang, maka orang tersebut akan sakit atau meninggal, apabila hal itu terjadi maka akan diadakan upacara managalaptondi (menjemput tondi)

Begu adalah tondi orang yang telah meninggal yang tingkah lakunya sama dengan tingkah laku manusia tetapi dengan cara terbalik dan hanya muncul pada waktu malam, biasanya masyarakat Batak Toba takut dengan Begu karena dianggap mengganggu dan jahat. Begu yang paling ditakuti adalah yang berasal dari orang yang meninggal mendadak, yang tidak mempunyai anak, wanita yang meninggal saat melahirkan ini jenis begu yang jahat luar biasa, kemudian meninggal karena menderita kusta, dan meninggal bunuh diri.

Pada masyarakat Batak Toba di Kecamatan Simanindo, agama yang banyak dianut oleh penduduk desa adalah Kristen, agama lainnya yang terdapat di kecamatan Simanindo yaitu Islam, Katolik dan ada beberapa kelompok masyarakat yang menganut kepercayaan Malim, dan disebut Parmalim. Demikianlah agama dan kepercayaan suku Batak Toba di Kecamatan Simanindo walaupun sudah menganut agama masing-masing namun tidak meninggalkan kepercayaan dan adat yang sudah tertanam dan diajarkan kepada mereka.

\section{f. Tata Pelaksanaan Upacara Adat} Kematian Saur Matua

$\underline{\text { a.Perencanaan }}$

Setelah seseorang meninggal dengan jenis kematian Saurmatua, maka berkumpullah semua anggota keluarga di rumah duka dan memberi 
kabar kepada anggota keluarga lainnya, sebagian memandikan dan mengganti pakaian orang yang telah meninggal dan membaringkannya di ruang tengah dean kakinya mengarah ke jabu (bona rumah suhut) beralaskan tikar anyaman dari daun pandan.Setelah tata acara selesai dirangkai, maka di buatlah silsilah keluarga dari orang yang meninggal tersebut

b. Pelaksanaan

1. Mangalap Pande Dohot Pargonsi

Mangalap Pande Dohot Pargonsi, biasanya dilakukan dimalam pertama setelah kematian. Sebelum upacara adat dimulai, biasanya pada upacara adat Saurmatua berlangsung dalam minimal 3 hari. Pada malam pertama setelah seseorang meninggal Saurmatua,pargonsi bersiap-siap untuk memainkan Gondang untuk pertama kali dan untuk hari berikutnya dengan tujuan untuk memberitahukan atau mengumumkan kepada masyarakat sekitar bahwa seseorang telah meninggal saurmatua, supaya masyarakat setempat hadir di rumah duka untuk turut menari bersama.

Adapun urutan Gondang yang dibunyikan pada malam pertama setelah kematian saurmatua adalah sebagai berikut :

\section{a. Sipitu Gondang}

Sipitu Gondang adalah salah satu gondang yang wajib dimainkan sebelum memulai gondang lainnya dan tidak boleh ada yang menari terutama pada upacara kematian Saurmatua. Hal ini menjadi khusus dikarenakan jenis gondang ini adalah antara pargonsi dengan Tuhannya, dimana pargonsi pasahat Harbue pir /Harbue satti siap meminta (marpangidoan tu Oppu Mulajadi Nabolon). Dan Sipitu Gondang ini dikenal sebagai gondang $n i$ namonding, pada sebagian masyarakat mengenal gondang ini sebagai Gondang Begu.

\section{b. Gondang Mula-mula} GondangMula-mula

merupakan jenis gondang yang wajib dibunyikan. Gondang ini dibunyikan untuk menggambarkan bahwa segala yang ada didunia ini ada mulanya, baik itu manusia, kekayaan dan kehormatan.SupayaTuhan 
memberkati dari awal hingga akhir acara saurmatua,dengan damai dan sukacita

\section{c. Gondang Somba}

Gondang Somba merupakan jenis gondang yang diminta oleh pihak Hasuhuton dan Boru supaya mereka menyampaikan persembahan rasa hormat kepada Hula-hulanya. Pihak suhut menari mendatangi Hulahula satu per satu meminta berkat dengan posisi menyembah dan dibalas dengan menaruh tangan diatas kepala suhut oleh Hula-hula.

d. Gondang Liat-liat

Gondang Liat-liat jenis gondang ini dilaksanakan dengan harapan Liat gabe liat horas, masyarakat menari sambil membentuk pola lingkaran dan mengelilingi mayat.

e. Gondang Parsahataan

Gondang Parsahataan biasanya diminta untuk menbunyikan gondang Simonang-monang,gondang ini mengartikan parsahataan $n i$ namarhaha-maranggi (se-ia sekata,senasib-sepenanggungan antara abang-beradik)

\section{f. Gondang Husip-husip}

Gondang Husip-husip dalam upacara kematian Saurmatua adalah jenis gondang yang diminta oleh pihak Hasuhuton supaya anggota keluarga menari bersama dan menyampaikan kata-kata terakhir kepada orang yang sudah meninggal saurmatua,hal ini sering disebut Mangalap Tua Sian Namonding.Tortor Husip-husipini dilakukan pada malam pertama setelah kematian atau dimalam kedua apabila pada malam pertama setelah kematian Saurmatuaada kegiatan lain yang harus dilakukan atau kematian terjadi pada sore hari maka demikian akan dilakukan pada malam kedua. Jadi biasanya gondang ini dilaksanakan dihari pertama atau kedua setelah kematian. Pada hari tersebut semua anak dan cucu-cucu dari orang yang telah meninggal saurmatua tersebut akan berkumpul mengelilingi jenazah maka gondang pun diminta dan mereka manortor, ketika adanya halangan akan pelaksanaan gondang tersebut akan digantikan dengan mandok hata tu namonding (berbicara dengan orang yang telah meninggal) dan masih ada sampai sekarang. 
g. GondangMarsiolop-olopan

Gondang Marsiolop-olopan

ini diminta oleh Raja Parhata supaya Hula-hula membalas tortor Somba yang dilakukan oleh Suhut kepada Hula-hula, sambil memberkati suhut dengan kedua tangan terbuka sambil memegang ulos dan menyentuh kepala, kemudian pihak suhut membalas dengan meletakkan tangan di wajah.

h. Godang Hasahatan Sitio-tio

Godang Hasahatan Sitio-tio merupakan gondang penutup ataupun mengakhiri setiap rangkaian Gondang, durasinya singkat dan dikenal dengan orang yang menari atau manortor mengangkat ujung ulos dan mengayunkan kedepan sambil mengucapkan kata Horas sebanyak tiga kali.

\section{Penutup}

Setelah upacara di dalam rumah selesai, biasanya pada hari ketiga akan dilakukan pemakaman. Setelah sarapan, pagi harinya peti jenazah pun di angkat keluar rumah (maralaman), maka raja parhata akan mengumumkan acara selanjutnya dan membacakan riwayat hidup seseorang yang meninggal Saurmatua tersebut.
Dalam kegiatan mangungkap hombung, pihak keluarga dan pihak dalihan natolu harus hadir, dikatakan mangungkap hombungartinya Tulangyang mengadakan ungkap hombung untuk menanyakan dan meminta harta yang ditinggalkan oleh seseorang yang saurmatua. Kegiatan ini diawali dengan pemberian makanan berupa ikan mas kepada pihak kemalangan atau suhut.

Kegiatan mangungkap hombungpada Saurmatua perempuan dan Saurmatua laki-laki akan berbeda bagi pihak peminta harta,seseorang yang meninggal laki-laki saurmatua, yang meminta harta adalah Tulangnya atau saudara laki-laki dari ibu yang meninggal saurmatua. dan harta yang diberikan berupa emas, sejumlah uang, didalam tandok kecil (Hajut) sampai tulang dari yang meninggal saurmatua tersebut merasa puas dengan pemberian tersebut, apabila masih kurang dia berhak untuk meminta lagi dan pihak keluarga tidak boleh menolak dan bahkan menambah sejumlah uang kedalam Hajut tersebut sampai tulang tersebut senang kemudian marumatondi-i semua anggota keluarga yang 
ditinggalkan dengan boras si pir ni tondi (beras)

g. Kajian Komunikasi Non Verbal dalam Tortor Husip-husip Pada Upacara Kematian

\section{Saurmatua}

Bentuk komunikasi non verbal merupakan salah satu bentuk komunikasi dimana penyampaiannya bukan dengan kata-kata ataupun suara tetapi melalui gerakan-gerakan anggota tubuh yang sering dikenal dengan bahasa isyarat atau body language. Makna yang dibawa oleh bentuk-bentuk non verbal adalah terikat dengan konteks, atau sebagian ditentukan oleh situasi dimana bentuk-bentuk non verbal itu dihasilkan. Baik bahasa dan bentukbentuk non verbal memungkinkan komunikator untuk menggabungkan sejumlah kecil tanda kedalam berbagai ekspresi atau ungkapan makna yang kompleks tanpa batas.

\section{PENUTUP}

\section{a. Saran}

Adapun saran-saran yang diajukan sesuai penelitian ini adalah sebagai berikut :
1. Melihat makna gerak tortor Husip-husip dalam upacara kematian saurmatua pada upacara adat Batak Toba memiliki peranan yang sangat penting diharapkan tradisi ini tetap dilaksanakan sebagai salah satu identitas seni budaya pada masyarakat Batak Toba

2. Generasi muda diharapkan dapat menggali/meneruskan tradisi Batak Toba supaya tidak punah dan tradisi Batak Toba dapat diperkenalkan ke publik nasional dan internasional

3. Kepadapara seniman, khususnya seniman Batak Toba agar terus berkarya dan menjaga utuh kesenian tradisional Batak Toba. 


\section{DAFTAR PUSTAKA}

Van Dijk.1954. Pengantar Hukum Adat Indonesia, PT Penerbit dan Balai Buku Ichtiar Djakarta.

Koentjaraningrat. 1960. Masyarakat Desa di Indonesia Masa Ini, JBP Fakultas Ekonomi, UI Jakarta

Hilman Hadikusuma.1976. Ensikpoledia Hukum Adat dan Adat Budaya Indonesia, Alumni Bandung.

Koentjaraningrat.1981. Sejarah Teori Antropologi. Jakarta : Universitas Indonesia.

Soedarsono, $1987 . \quad$ Tari-tari Indonesia. Jakarta : Direktorat Jenderal Kebudayaan.

Bungin, Burhan (ED). 2001. Metodologi Penelitian Kualitatif. Jakarta : PT Raja Grafindo Persada.

Debora, Ester. 2012. Gondang Sabangunan pada Tortor Sigale-gale di Desa Tomok Kecamatan Simanindo Kabupaten Samosir. Skripsi. Universitas Negeri Medan

Nugrahaningsih, RHD dan Heniwati, Yusnizar. 2012. Tari Identitas dan Resistensi. Medan : Unimed Press.

Simarmata, Golda, 2013. "Husiphusip dalam tortor Hatasopisik pada masyarakat Toba kajian Interaksi Simbolik'Medan : Universitas NegeriMedan. 